\title{
A IMAGEM DA VIOLÊNCIA NO DOCUMENTÁRIO CINEMATOGRÁFICO BRASILEIRO
}

THE IMAGE OF VIOLENCE IN BRAZILIAN DOCUMENTARY FILM

THE IMAGE OF VIOLENCE IN BRAZILIAN DOCUMENTARY FILM

LA IMAGEN DE LA VIOLENCIA EN EL DOCUMENTAL BRASILEÑO

\section{Resumo}

Isabel Padilha Guimarães

Doutora PUCRS

isabelpadilha@yahoo.com.br

O artigo tem por objetivo a análise da imagem da violência no cinema documentário brasileiro, utilizando, como objeto de estudo, um conjunto de cinco documentários, realizados entre 2002 e 2004: Ônibus 174 (José Padilha, 2002), Fala tu (Guilherme Coelho, 2003), O cárcere e a rua (Liliana Sulzbach, 2004), O prisioneiro da grade de ferro (Paulo Sacramento, 2004) e Justiça (Maria Augusta Ramos, 2004). Objetiva-se o exame das particularidades da violência, buscando compreender a relação entre os elementos culturais e cinematográficos que conduzem à constituição de um imaginário. Considerando a apropriação da realidade realizada pelo cinema, busca-se a apreensão desta relação, observando como o social se realiza na narrativa cinematográfica. Os documentários selecionados são tentativas de desvelamento das situações de violência apresentadas. Sob este aspecto, o foco volta-se para o ser humano, seja ele policial, vítima ou bandido, no sentido de ver e compreender uma situação de violência que já faz parte do cotidiano, em todas as camadas da sociedade.

PALAVRAS-CHAVE: Cinema. Documentário. Violência urbana.

\begin{abstract}
The aim of this article is to analyze the image of violence in Brazilian documentary film. The object of this study is a set of five documentary films produced between 2002 and 2004: Ônibus 174 (José Padilha, 2002), Fala tu (Guilherme Coelho, 2003), O cárcere e a rua (Liliana Sulzbach, 2004), O prisioneiro da grade de ferro (Paulo Sacramento, 2004) and Justiça (Maria Augusta Ramos, 2004). The goal is to examine the particularities of violence, making an effort to understand the relationship between cultural and cinematic elements that lead to the constitution of an imaginary. Considering the appropriation of reality through cinema, we try to apprehend this relationship by examining how the social approach takes place in filmic narrative. The chosen documentary films are attempts to disclose the processes of violence which are shown. From this point of view, the focal point lies in the human being, be it the policeman, the victim or the thief, in the sense of seeing and understanding a process of violence that is already part of everyday life in all social strata.
\end{abstract}

KEY WORDS: Cinema. Documentary. Urban Violence. 


\section{Resumen}

El objetivo del presente artículo es el análisis de la imagen de la violencia en el documental brasileño, utilizándose, como objeto de investigación, de un conjunto de cinco documentales hechos entre los años de 2002 y 2004: Ônibus 174 (José Padilha, 2002), Fala tu (Guilherme Coelho, 2003), O cárcere e a rua (Liliana Sulzbach, 2004), O prisioneiro da grade de ferro (Paulo Sacramento, 2004) y Justiça (Maria Augusta Ramos, 2004). Se trata de examinar las particularidades de la violencia, buscando entender la relación de los elementos culturales y cinematográficos que llevan a la constitución de un imaginario. Considerándose la apropiación de la realidad llevada a cabo por el cine, se busca la aprehensión de esa relación, observando como el social se realiza en la narrativa cinematográfica. Los documentales elegidos son intentos de desvelo de las situaciones de violencia presentadas. Considerando ese aspecto, el foco se vuelve hacia el ser humano, sea él policía, víctima o malhechor, en el sentido de ver y comprender una situación de violencia que ya hace parte del cotidiano en todas las capas de la sociedad.

PALABRAS CLAVE: Cine. Documental. Violencia Urbana.

\section{INTRODUÇÃO}

O tema da violência invadiu o imaginário social e a sua presença também é constante no cinema. Labaki (2005, p.197), por exemplo, refere-se “à explosiva criminalidade brasileira”, que pauta análises audiovisuais, a partir da presença do Brasil das ruas, morros, delegacias, tribunais e cárceres nas telas de cinema. Na compreensão do trajeto do conjunto de filmes que compõe este artigo, se busca o exame da sua contribuição para a construção das imagens da violência exibidas no cinema. Pois se o imaginário é alimentado pelas imagens, o contrário também ocorre, “a existência de um imaginário determina a existência de um conjunto de imagens” (MAFFESOLI, 2001, p.76). Neste sentido, o cinema articula o emocional e a técnica, através da veiculação das imagens. Assim, as questões principais giram em torno da relação que o cinema pode estabelecer conosco e das relações específicas que os filmes criam, além da afinidade do significante cinematográfico com a constituição de um imaginário.

O cinema brasileiro atual tem sido uma das áreas mais reflexivas em relação ao dilema da violência na sociedade brasileira. Segundo Rossini (2003, p.29), mesmo não se tratando de um assunto novo, "falar de favela se tornou assunto recorrente no cinema nacional”, em função do tráfico de drogas e da sua repercussão nos meios de comunicação. $\mathrm{Na}$ análise dos cinco documentários, se objetiva o exame das particularidades da violência, que conduzem à constituição de um imaginário, observando em que medida se encontra situada em suas representações no cinema. Levando-se em conta a compreensão da relação 
dos elementos culturais e cinematográficos que levam a sua percepção, a partir de que aspectos, no interior de cada filme, ocorre a sua manifestação? Qual a relação das imagens da violência manifestas na sociedade com as imagens da violência observadas na narrativa cinematográfica? Objetiva-se a investigação da violência urbana como fenômeno social e a sua presença nos documentários cinematográficos brasileiros eleitos como corpus deste artigo.

Os documentários tratam das representações de histórias pessoais que refletem questões mais amplas, relativas ao social e à política, visto que as pessoas retratadas são abordadas individualmente, mas também estão situadas em determinado lugar e em relação a outros. Evoca-se o fato de que a sociedade não é somente contratual, pois também se encontra sob a criação e a partilha de imagens (METZ, 1980). Assim, o cinema constitui uma das formas para se apreender diferentes configurações de práticas sociais, visto que se caracteriza por estabelecer enunciados sobre o mundo histórico. Diante disso, o mundo imaginal constitui-se num modo de considerar a relação espaço-tempo, que se torna determinante para a compreensão de qualquer sociedade. Com este propósito, o objetivo desta pesquisa é a análise e interpretação do que um filme pode revelar sobre o mundo em que se vive e as maneiras pelas quais dá expressão a valores e crenças, ligadas ao imaginário da violência, que constroem ou contestam formas de pertença social, a partir de cinco documentários, produzidos entre os anos de 2002 e 2004, que estudados em conjunto, formam um encadeamento, através da sucessão de alguns aspectos ligados à violência.

O conjunto de filmes mostra pessoas que convivem com a violência, em favelas, (Fala Tu), apresenta um sequestro à mão armada (Ônibus 174), observa os tribunais e processos de julgamento (Justiça), as prisões ( $O$ prisioneiro da grade de ferro) e o momento do trânsito entre o cárcere e a rua, em busca da liberdade perdida ( $O$ cárcere e a rua). Nos filmes, se constata a presença dos aparatos estatais de prevenção, julgamento e punição, respectivamente, representados pela polícia, pelos tribunais e pelas prisões. Nesta perspectiva, cada filme constitui uma peça, compondo uma sucessão, na qual cada obra tem seu projeto próprio, mas que, quando vistas em conjunto, dizem algo de seu presente, mesmo sem ter essa ambição. Esta opção temática por filmes que abordam a questão da violência indica o ponto de observação a partir do qual, inúmeros filmes foram realizados, em diferentes circunstâncias, aspectos e estilos.

Serão utilizadas algumas cenas que servirão de apoio e ilustração para pontos da análise que dialogam com a questão da representação e do contexto que envolve o filme, a 
partir da concordância com a concepção de Gilberto Velho (1999, p.57) de que "a ideia de que estabilidade, harmonia e integração são fenômenos naturais ou normais não é necessariamente legítima”, visto que a vida social é um processo contraditório e complexo, permanentemente negociado por diferentes atores sociais. Questão que se complexifica no documentário, com o acréscimo da linguagem cinematográfica, que não só apresenta como constrói o mundo vivido.

\section{O REFLEXO DA VIOLÊNCIA}

É interessante observar que, diariamente, há uma avalanche de notícias sobre violência, em diferentes meios de comunicação. No jornalismo, se lida com o fator tempo, quase sempre escasso, no percurso do ciclo, que vai da apuração à divulgação dos fatos. Neste panorama, nas informações veiculadas, as fontes são a polícia e a sua ação sobre os bandidos e as vítimas. Com os depoimentos de ambos, realiza-se o chamado “jornalismo declaratório”.

A propósito, no formato tradicional de telejornal, também se pode observar o "efeito Kuleshov". Trata-se da famosa experiência, desenvolvida pelo cineasta russo Lev Kuleshov, na qual ele dispôs a imagem da fisionomia inexpressiva de um homem, seguida por diferentes imagens, alternadamente, tristes e alegres, como um bebê risonho ou uma mulher morta. A expressão do homem era interpretada, segundo a imagem que era mostrada em seguida. $\mathrm{O}$ sentido de uma imagem depende, então, daquelas que a precedem no decorrer do filme e a sucessão delas, que cria uma nova realidade, não equivalente à simples adição dos elementos empregados. No caso dos telejornais, as notícias sobre violência são intercaladas com notícias sobre esporte, entretenimento e política, por exemplo. A passagem é feita pelo apresentador, que em segundos, transita de uma expressão carregada para outra mais suave. Não se trata, portanto, de uma soma de imagens, mas de uma forma temporal, que altera o sentido do que é apresentado.

Em sociedade, mídia e violência, Muniz Sodré (2006, p.100) qualifica como "atmosfera generalizada de horror show", o ambiente caracterizado pelo "sofrimento do outro e o medo coletivo" produzidos como espetáculo, em que os temas da catástrofe e da insegurança pública são recorrentes na mídia, cuja abordagem é marcada pela dramaticidade e pela espetacularidade, com a evocação de discursos moralistas em torno do assunto. Com a constante advertência midiática para os riscos de catástrofe, apela-se à proteção dos detentores do monopólio legítimo da violência. Trata-se do Estado, com seus dispositivos armados, 
legitimando a existência de seus aparelhos repressivos e "ensejando o desenvolvimento de uma ideologia policialesca de vigilância e de segurança públicas” (SODRÉ, 2006, p.100).

Geralmente, os noticiários televisivos mostram a vítima, que tem medo e ódio do agressor, e, de outro lado, o agressor, indiferente à vítima, seja esta quem for, mas que também, à sua maneira, tem medo dela (BAIERL, 2004, p.68). Deste modo, se configura a relação entre ambos, na qual o outro passa a ser visto como um inimigo, ordenando-se, deste modo, a separação dos sujeitos, baseada na concepção da identidade clássica e estável, desconsiderando o "tornar-se outro" e a sua conexão com mundo.

Em relação às histórias e aos relatos das pessoas apresentadas nos documentários, o privado e o público se interpenetram e se reestruturam, visto que a vida particular de cada personagem relaciona-se com o coletivo. Segundo Bourriaud (2009, p.21), a arte sempre foi relacional em diferentes graus, constituindo-se em fator de socialidade e fundadora de diálogo, mantendo juntos, momentos de subjetividade ligados à experiência singular. Assim, a relação com o outro determina o que se é. "Neste sentido, a experiência não é vivida por um ego forte e solitário, ela deve ser dita, contada, vista” e, numa perpétua encenação, ela introduz numa lógica que, de parte a parte, é relacional (MAFFESOLI, 1999, p.92).

Observa-se que a compreensão da violência e seu imaginário não ocorrem através da apresentação de causas, explicações ou argumentos. Segundo Machado da Silva (2003, p.62), "somente o choque perceptivo pode interferir no imaginário, cujas tecnologias trabalham com as linguagens da sedução, no universo empático da compreensão”. Neste contexto, se encontra o estatuto dos filmes brasileiros recentes sobre violência, sejam documentários ou ficções, que encontraram viva ressonância na nossa sociedade e passaram a pautar também, produções televisivas. Sob este aspecto, é pertinente a expressão “mundo imaginal”, empregada por Maffesoli (2003, p.67), para designar um mundo no qual as imagens, imaginações e símbolos, sob suas diversas modulações, são elementos essenciais do laço social, visto que o imaginário é constituído a partir de imagens e vice-versa.

\section{HOMO VIOLENS $x$ CINEMA}

Para Dadoun (1998, p.10), não há qualquer aspecto da realidade humana que não seja, de alguma maneira, associado à violência. Ela também cobrirá tudo o que tem relação com força, potência, poder e energia. Dadoun se pergunta se a arte - e aqui, estendemos o seu questionamento para o campo do audiovisual, em particular, o cinema - com seu poder e suas ambiguidades, não seria o mais seguro sustentáculo do homo violens, na sua eterna queda de 
braço com a violência. Afirma que é preciso efetuar uma espécie de desprendimento e ver a violência com um outro olhar: o da arte, passando assim, do campo de forças para o campo das formas. É dado o exemplo da pintura expressionista de Van Gogh que, “através de seu movimento explora a louca complexidade do homo violens - preso, numa rede, num cálculo, numa intensidade, num gozo estético - graças ao efeito da arte” (DADOUN, 1998, p.108).

Uma das críticas feitas por Zaluar (2005, p.2), refere-se ao fato da mídia se debruçar, sobretudo, sobre estatísticas relativas a número de mortos e danos físicos causados pela violência, por se tratarem de elementos visíveis e publicizáveis. Mas neste caso, o cinema constitui-se num espaço que, ao privilegiar a abordagem da violência em contextos particulares, relativos às pessoas retratadas, possibilita que além dos mortos e feridos, leve-se em conta os sofrimentos morais e psíquicos, que ao contrário, são impalpáveis.

Na relação dos filmes abordados, é a combinação destas duas circunstâncias, que é a situação individual de cada personagem e a sua organização fílmica, proporcionada pelo estilo mosaico, que estrutura a narrativa a partir dos momentos particulares das várias pessoas retratadas, que ocorre a contextualização da violência, em determinado tempo e lugar. Constata-se que os documentários possuem roteiros com estruturas semelhantes. Cada um apresenta várias histórias que são contadas de forma alternada, seja por semelhança ou contraste. Identifica-se a referência à atuação dos aparatos estatais de prevenção, julgamento e punição, que se atribuem, respectivamente, à polícia, ao judiciário e à prisão. As personagens, em sua totalidade, se encontram em uma posição marginalizada, em áreas consideradas periféricas, como favelas e presídios.

São mostradas as formas de reação ao medo, de enfrentamento ou passividade frente às diferentes manifestações de violência, através da busca de alternativas na esfera do privado. Os filmes apresentam esta resistência à violência, sob o ponto de vista dos criminosos ou réus, a partir do momento em que estão sob a jurisdição do Estado. No documentário Fala Tu, cujas personagens são moradores de favelas ou subúrbios, o discurso empregado atribui as dificuldades econômicas e sociais à incompetência do Estado e à desigualdade de classes, através da dicotomia entre pobres e ricos, estes últimos chamados de playboys. Também manifestam a queixa contra a repressão policial e não à violência exercida por traficantes ou bandidos. São pessoas que estão submetidas a vinculações verticais e hierarquizadas, a partir do relacionamento com as instituições públicas.

Neste panorama, o cinema tem o poder de evocar a teatralidade cotidiana, que se fundamenta na duplicidade, no jogo da troca de máscaras e nos múltiplos papéis que a pessoa 
é chamada a desempenhar, explorando a força da alteridade, que não se pode negar (MAFFESOLI, 2003). Esta força pode ser estigmatizada e marginalizada, mas, ainda que em forma de sombra, está presente. Segundo Maffesoli (2003, p.66) “até mesmo o Deus da tradição ocidental é obrigado a tolerá-lo, na pessoa de Satã”. A violência é um elemento essencial da construção simbólica do social.

O imaginário da violência não será observado como observaríamos os fatos. É sentido como a percepção no mundo real, com o diferencial do acréscimo da música, da montagem e dos diversos componentes cinematográficos que compõem um filme e que conduzirão o espectador. Observa-se a violência sofrida pelas pessoas retratadas, e não a violência, eventualmente, por elas praticada, nem tampouco, as suas vítimas, como é o caso dos filmes $O$ prisioneiro da grade de ferro, O cárcere e a rua e Justiça, cujas personagens se encontram presas ou aguardando julgamento. São mostradas as condições em que vivem nas prisões. Trata-se de pessoas que perderam a voz e a visibilidade, a partir da sua condição de presidiárias ou rés. Em Ônibus 174, se observa, efetivamente, a violência exercida pela personagem principal, ao mesmo tempo em que se constata a violência, por ela sentida, ao longo dos anos, desde a sua infância. E em Fala Tu é abordado o cotidiano de três pessoas, moradoras de subúrbios, que em seus depoimentos, demonstram o descontentamento com a própria situação econômica e social e com a violência policial. Estes filmes não se referem exatamente ao ato de violência explícita, mas se baseiam no que seria o dia-a-dia de precariedade destas pessoas.

Há dificuldade em se definir violência, dada a diversidade de definições que podem ser propostas. Aqui, se busca uma definição que dê conta tanto dos estados quanto dos atos de violência. Segundo Michaud (2001, p.10),

há violência quando, numa situação de interação, um ou vários atores agem de maneira direta ou indireta, maciça ou esparsa, causando danos a uma ou várias pessoas em graus variáveis, seja em sua integridade física, seja em sua integridade moral, em suas posses, ou em suas participações simbólicas e culturais.

A sociedade preocupa-se com uma crescente insegurança, que não tem apenas a ver com o volume efetivo da criminalidade, mas também diz respeito às normas, a partir das quais são concebidos os fenômenos criminosos (MICHAUD, 2001, p.33). Na noção de violência se encontra a ideia de uma força, de uma potência natural cujo exercício contra alguma coisa ou contra alguém torna o caráter violento. 
A violência é assimilada ao imprevisível, à ausência de forma, ao desregramento absoluto. Como transgressão das regras e das normas, deixa entrever a ameaça do imprevisível. A caracterização de alguma coisa-ato, comportamento ou situação, como violência, pressupõe a atribuição de um valor (MICHAUD, 2001, p.12). Por isso, é um erro pensar que a violência pode ser concebida e apreendida independentemente de critérios e de pontos de vista.

É relevante a observação da classificação indicativa dos filmes, aqui analisados, nas capas dos seus DVDs. O filme Fala Tu, por exemplo, traz a classificação: “violência leve”. O filme $O$ cárcere e a rua exibe a qualificação de: "violência leve, violência (ameaça), violência (assassinato)”. O próprio termo “violência” já supõe julgamentos de valor, que nos exemplos, infere uma conotação negativa muito marcada, mesmo que não existam imagens que conduzam às categorizações apresentadas. Segundo Yves Michaud (2001, p.111), a relatividade e o caráter indefinível do conceito de violência não são de modo algum acidentais, mas inerentes a um tipo de noção que polariza a diversidade conflitiva das avaliações sociais: os mesmos fatos não são apreendidos, nem julgados segundo os mesmos critérios.

Joron (2005, p.10) observa que a violência é um conceito mole, uma neblina conceitual. Dentro da violência, existe o eixo de encontro com o outro. Genericamente, se trata de "uma força individual ou coletiva, física ou psicológica, justificada ou não, que exprime um estado ou satisfaz uma necessidade imediata, ou serve para modificar uma situação, manter uma ordem satisfatória”. A definição de violência embaraça-se, devido à polifonia de seu significado e à multiplicidade de manifestações. Segundo Zaluar (2005, p.8), o que dá sentido e foco para a ação violenta é a sensibilidade mais ou menos aguçada para o excesso no uso da força corporal ou de um instrumento de força e o conhecimento maior ou menor dos seus efeitos maléficos, seja em termos de sofrimento pessoal ou de prejuízo à coletividade.

A propósito, constata-se que nos filmes $O$ prisioneiro da grade de ferro, Justiça e Ônibus 174, há a ocorrência de uma frase, constantemente repetida pelos detentos que são mostrados. É pronunciada durante uma reza, na declamação de uma poesia e pode até ser lida em uma parede: “paz, justiça e liberdade”. Quem não acompanha o noticiário ou mesmo, está fora do âmbito político e social brasileiro, provavelmente fará uma leitura particular, sem considerar o seu entorno e desconhecendo o fato de tratar-se do lema do Comando Vermelho, uma das maiores organizações criminosas do país, criada nos anos 60. Esta força existe em 
um contexto sociocultural, tratando-se de um revelador eficaz e útil dos nossos modos de ser em sociedade e dos nossos modos de excluir.

Joron (2005, p.11) faz uma distinção entre violência privada e coletiva, que possuem repercussões morais diferentes. A coletiva pode ser usada para chamar a atenção do Estado sobre os seus disfuncionamentos. Pode ser um catalisador de mudança social. A privada (individual) é denunciada com mais facilidade, porque é pouco concebida moralmente. É considerada uma intrusão, pois a sua consequência é a morte ou pessoas atingidas física e moralmente. Como é mais individual, podemos nos colocar no lugar das pessoas feridas e atingidas. No filme $O$ prisioneiro da grade de ferro, são mostrados presos preparando crack, os facões usados para se defender, fotos de detentos mortos dentro da cadeia, as celas de castigo, etc. Em Ônibus 174, se pode acompanhar depoimentos de bandidos e policiais, descrevendo o que sentem quando matam. Além do ato de violência explícita, através de Sandro com sua arma na mão, esta também é sugerida pelo clima de extrema precariedade. A morte está permanentemente presente. Afora sua manifestação física, impregna todos os atos da vida cotidiana.

A violência é revelada do ponto de vista de quem a pratica e de quem sofre as suas consequências. Sob este aspecto, o incomum não é o que, mas quem conta. E o cinema se torna o espaço singular perante o qual estas pessoas terão corpo e voz. O discurso do bem e do mal está presente nas falas das personagens, ao discorrerem sobre os riscos a que estão expostas, as dificuldades financeiras e, principalmente, a exclusão social. A fala do personagem Toghum, no filme Fala Tu é reveladora: “eu já nasci excluído. Se eu não me direcionar para sair dessa camada de excluídos, nem que seja dez porcento, ninguém vai fazer por mim. Não precisa nem viver tão bem, mas viver”. Esta fala reflete a sobrevivência das pessoas explorando suas possibilidades. A violência aparece como algo corriqueiro, típico do dia-a-dia das pessoas, que se expressa no conjunto das relações sociais e na vida cotidiana, através do desemprego, qualidade dos serviços públicos, desrespeito, perda da dignidade e ausência de cidadania, que vai minando o cotidiano dos sujeitos (BAIERL, 2004, p.52).

Em Fala Tu, por exemplo, Macarrão se refere às suas músicas em estilo rap, como crônicas do cotidiano e declara: "bandido e trabalhador vão gostar da minha música, mas playboy e polícia não”. Outro personagem, apelidado de DJ A, cuja esposa sofre um assalto, afirma indignado: “os bandidos têm que roubar na zona sul, não na zona norte”. Em $O$ prisioneiro da grade de ferro, através do verso cantado por um detento e sua banda, chamada Sobreviventes do rap: "Carandiru, casa do diabo, sua vida se transforma num verdadeiro 
inferno”. Além de detentos, que se referem às pedras de crack que enrolam como “a raspa da panela do diabo". No filme Ônibus 174, há o personagem Sandro, que ordena à sua vítima que escreva frases no para-brisa do ônibus: "ele têm um pacto com o diabo", "ele vai matar geral”. Ele olha para as câmeras de televisão, revela que estava na chacina da Candelária e brada, aos gritos: “pode filmar prá todo Brasil olhar mesmo”.

A violência permanece no horizonte das relações e na maneira como é percebida, o que conta tanto quanto a violência efetiva (MICHAUD, 2001, p.60). Ocorre a integração e a visibilidade desse mal. É o que permite entender o surgimento e o desenvolvimento da violência e das comunidades de condenados pela justiça que se formam, em presídios, por exemplo, e que são denominados de bandidos, criminosos, assaltantes, marginais, etc., independentemente da gravidade do crime cometido, que pode variar de um roubo de telefone celular a um homicídio.

A problemática da violência sempre sofreu com uma concepção binária das coisas, como se esta fosse exterior ao elo social e como se este último não se servisse e mesmo não produzisse à violência. A partir do esquema projeção-identificação, é perfeitamente possível a identificação com o traficante, o morador da favela ou o policial. Porque os personagens são apresentados em sua multiplicidade. A fenomenologia da violência cotidiana está presente nas mímicas, gestos, palavras, posturas, no espaço no qual as pessoas atuam, etc.. A maioria dos filmes não apresenta a violência explícita e o que se observa é um estado de violência aparente, a partir do cotidiano das pessoas enfocadas que participam, ao mesmo tempo, das instituições, do mercado, da empresa, da vizinhança pobre e da família. As suas falas, registradas em entrevistas, mostram as relações e as superposições entre esses vários mundos e o saber, por elas, acumulado a respeito das falhas, incoerências, discriminações e hipocrisias das instituições jurídicas (ZALUAR, 2004, p.22).

Os documentários partem das histórias de vida de suas personagens, para, a seguir, delinear situações sociais de suas vidas, nos diversos espaços citados anteriormente, como a favela, o tribunal e o presídio. Revela-se o cotidiano marcado por uma situação material de precariedade e o seu modo de se relacionar com o mundo. São pessoas que ocupam posições periféricas na nossa sociedade, além de não viverem a experiência do mercado de trabalho. Se utilizam de estratégias de sobrevivência, como a colocação no trabalho informal, por exemplo. Além de habitarem lugares como ruas, favelas e presídios que são identificados como ambientes deteriorados, sujos, característicos do não-trabalho e da vagabundagem. 
Estes aspectos e as pessoas que moram nestes locais são associados à violência e ao crime (CALDEIRA, 1984, p.166).

No filme Fala Tu, as três personagens são situadas, na abertura do filme, através de seus apelidos, idades e os tipos de trabalho realizados. A alteridade também é marcada através da opção religiosa de cada um. Toghum tem 32 anos, é vendedor autônomo e budista. Combatente tem 21 anos, é telefonista e pratica o santo daime. Macarrão, aos 33 anos, é apontador de jogo do bicho e sua família é evangélica. Todos têm em comum, o desejo de viver exclusivamente da música em estilo rap e a decepção por não conseguirem. Em $O$ cárcere e a rua, a atenção é dividida entre três mulheres, no trânsito entre o confinamento e a liberdade. Cláudia, Betânia e Daniela são identificadas pelos seus nomes, através de cartelas. Ocorre uma série de entrevistas com as detentas, que são associadas a cenas do cotidiano de cada uma delas. Estes documentários buscam recuperar histórias, em um processo que procura dar forma, nome e visibilidade a uma identidade. Os filmes revelam experiências pessoais que reverberam questões sociais mais amplas, encarnando perspectivas que compartilham histórias de exclusão.

Diferentemente dos dois exemplos, O prisioneiro da grade de ferro e Justiça abordam vários personagens, mas não há, de fato, um aprofundamento psicológico relativo à personalidade ou às motivações das pessoas apresentadas, pois nos dois casos, o foco prevalece nas ações realizadas no cotidiano, na construção dos espaços do presídio e do tribunal, levando-se em conta o seu mecanismo de funcionamento e a imagem da atuação das instituições públicas, marcada pela incompetência do Estado que resultaria em um universo de pobreza e miséria para as pessoas retratadas.

A construção do personagem também pode estar predominantemente, concentrada em um único sujeito ao longo do filme - como o caso de Sandro em Ônibus 174. Nesta situação, o personagem é objeto de relatos. Há a combinação do momento decisivo, definidor do seu destino, com o retrospecto da sua história, constituída por depoimentos e o levantamento de informações através de documentos. O sequestrador do ônibus 174 é negro, pobre e invisível socialmente.

Existe uma tendência à dicotomização de mundos - o dominante ou marginal, o incluído e o excluído. O foco em divisões deste tipo impede o entendimento das passagens múltiplas e das trocas contínuas que se articulam e tornam, por exemplo, frágeis, a fronteira entre o legal e o ilegal, o público e o privado (ZALUAR, 2005, p.7), visto que a violência se manifesta diferenciadamente na sociedade, afetando o cotidiano das pessoas e a coletividade 
de maneiras distintas. Segundo Baierl (2004, p.22), o medo, produzido e construído a partir da forma como a violência vem se materializando na sociedade, cria novas alternativas de sociabilidade, alterando o modo de ser e de agir das pessoas, dos grupos e das comunidades em seu cotidiano.

Além disso, o mundo do crime organizado não está tão distante do mundo empresarial e do mercado, com seus valores e suas regras. Seja na linguagem cotidiana ou nas relações com a família, o vizinho e o trabalhador. Segundo Zaluar (2004, p.21), muitos participam simultaneamente do mundo do trabalho e do crime. Sua adesão a uma atividade que os coloca cotidianamente em contato com a morte e com a guerra, faz dos criminosos, personagens trágicos, em conflito consigo mesmos, com seus parceiros e com suas prováveis vítimas.

Existe uma equação entre a violência e a igualdade e ocorre porque ela denuncia a extrema necessidade de hierarquização. A violência, no mundo brasileiro, é um instrumento utilizado quando os outros meios de hierarquizar uma dada situação falham irremediavelmente. Deste modo pode-se equacionar o "Você sabe com quem está falando?" com a violência. Em ambos os casos, o objetivo é a separação radical de papéis sociais, rompendo assim, com o individualismo. Se o ator está só no momento da violência contra o outro, ele não está mais só quando se trata de sustentar ou legitimar sua ação, o que é sempre realizado de modo coletivo, podendo-se então, saber com certeza, quem está do lado de quem.

É o que se vê nos filmes, cujas histórias se passam em presídios. Segundo Damatta (1981, p.191), em nosso universo social, à falta de relações de compadrio, altas amizades e laços poderosos de sangue, lança-se mão da violência como o único padrinho possível, que passa a ser um mediador básico entre a massa de destituídos e o sistema legal e impessoal que torna a exploração social “inevitável” e "justa” aos olhos dos dominantes. O que teoricamente teria que ser uma situação de igualdade entre todos os presos, reproduz os mecanismos da sociedade. Este fato é visto, inclusive, na compartimentação das áreas das penitenciárias, dos tribunais e das favelas. As pessoas passam a ser qualificadas pelo espaço que ocupam e por aquilo que não tem, habitando locais considerados periféricos.

Na interpretação da concepção de um espaço, como o presídio, por exemplo, podese compreender a sociedade com suas redes de relações sociais. O que se observa é que os vínculos hierarquizados são reproduzidos neste local e a ameaça da violência física se torna uma espécie de garantia para a manutenção dessas relações. Seja a violência entre detentos, dos guardas contra os detentos e vice-versa. Constata-se um hiato entre os princípios da 
instituição carcerária e as suas práticas, pois a rotina e a organização do local, depende da população que nela vive, tendo pouca relação com a ideia que dela se pode fazer, relacionada à manutenção da ordem e ao cumprimento das penas (MICHAUD, 2001, p.64).

Segundo Zaluar (2002, p.21), a violência não se refere aos critérios de uma civilização, nem às regras de uma sociedade dada, nem mesmo a um tempo histórico determinado, estando presente, mesmo que limitada ou relativamente controlada, em todas as culturas. Quando a violência irrompe, ela é governada não apenas pelo cálculo racional, mas pela paixão ou pela emoção descontrolada, se propagando num circuito de vinganças e de prazeres destrutivos. Além disso, cria um imenso abismo entre o que detém o instrumento, que obriga à submissão, e a sua vítima, que não tem defesa e nem recurso.

\section{A VIOLÊNCIA PERFORMÁTICA}

Esther Hamburger (2007), no seu artigo intitulado Violência e pobreza no cinema brasileiro recente, questiona o que ela denomina de papel da visualidade, isto é, o que merece ou não se tornar visível. Sob este aspecto, evoca-se o âmbito da visualidade cinematográfica, que nos interessa para esta discussão. Filmes como Notícias de uma guerra particular (1999), Cidade de Deus (2002), O invasor (2003), entre muitos outros, ao acentuar a presença visual de cidadãos pobres, negros e moradores das periferias, estimularam e intensificaram a “disputa pela definição de que assuntos e personagens ganharão expressão audiovisual, como e onde” (HAMBURGER, 2007, p.114). É determinante que se pense sobre o tipo de imagem de periferia, pobreza e violência, construída pelos filmes. Tornou-se até um clichê a afirmação de que só se faz filmes sobre violência no Brasil, dada pela impressão da quantidade e da repercussão dos filmes produzidos.

Ao examinar o debate em torno da adequação da representação midiática da periferia, Esther Hamburger (2007, p.120) observa que a recente exposição de representações da pobreza, em geral associada à violência, aumentou e se sofisticou no cinema, num processo que estimula a disputa em torno do controle do que merece e do que não merece se tornar visível. Até mesmo os cineastas adquiriram certa relevância para a discussão da violência urbana e passaram a ser tratados como especialistas do assunto. Quando se estuda uma cinematografia ou o que uma sociedade permite representar dela num espaço sociocultural, pode-se aproximar à questão do estereótipo, que colabora na formação do imaginário. No caso do Brasil, o estereótipo é a violência que está no cotidiano e na banalidade. 
Condizente com esta ideia, Fernão Pessoa Ramos (2003, p.14), no artigo intitulado Narcisismo às avessas, chama a atenção para a representação acentuadamente negativa de aspectos da vida social brasileira, por meio de mecanismos de catarse, que se realiza a partir do estabelecimento de uma dualidade maniqueísta entre povo idealizado e Estado incompetente. É definido como "naturalismo cruel”, o prazer que toma a narrativa em deter-se na imagem da exasperação ou da agonia, em obras-chave da produção cinematográfica brasileira.

Segundo Ramos (2003, p.14), “a imagem da miséria, da sujeira, a ação dramática em ambientes fechados e abafados (como prisões ou favelas), surge de modo recorrente. Ações com requintes cruéis de violência são exibidas em toda sua crueza”. Esta referência encontrarse-ia no fato do cinema brasileiro contemporâneo apresentar aspectos "bestiais e repulsivos da vida” de forma crua e desagradável. Mas Ramos não faz distinção sobre este tipo de representação na ficção e no documentário. No que se refere aos filmes estudados, estes circunscrevem a sua base no cotidiano precário, não transpondo certas fronteiras. O cinema lida com o imaginário construído sobre situações de violência e precariedade e não com as realidades vividas, relativas, por exemplo, às cenas "reais" como as presenciadas pelas pessoas que "sofrem na pele" com a violência.

O que é mostrado exige uma justificação ética, que não é reivindicada quando se trata da ficção. O filme Ônibus 174 expõem um ato de violência, no instante em que a refém é alvejada, enquanto se encontra sob o domínio do sequestrador. Segundo Zaluar (1986), o ato de matar uma pessoa não é julgado a priori, como um crime, segundo uma concepção universal de justiça. A avaliação moral deste ato depende de quem foi morto, se pertencia ou não à comunidade e em que circunstâncias isso ocorreu. Vale ressaltar, que as cenas já haviam sido exibidas, ao vivo, pela televisão e exaustivamente reprisadas nos dias que se seguiram ao sequestro do ônibus. Este fato é condizente com a ideia de que a câmera em ação, no caso citado, é menos vulnerável à acusação de comportamento não ético, porque as imagens foram feitas acidentalmente e o evento da morte é compartilhado com certo espanto, tanto pelo cinegrafista como pelo público que lá se encontrava.

Frequentemente, assiste-se no noticiário televisivo, tiroteios, pessoas de arma em punho ameaçando suas vítimas, etc.. Pois, não obstante, a exibição de certas circunstâncias, como a morte, por exemplo, constitui-se em um tabu social no documentário, pois conforme Sobchack (2005), a sua representação consiste em um excesso de visibilidade, uma vez que é vivenciada como uma experiência que tem origem no real. 
Baierl (2004, p.23) se refere à hipótese de que "a violência e o medo combinam processos que alteram a arquitetura urbana, segregando grupos em espaços sociais e discriminando certos segmentos”. Exemplifica a questão, examinando entrevistas realizadas por ela, que indicam que uma criança moradora da favela não se espanta ou se assusta com um cadáver no chão, enquanto uma criança de classe média, provavelmente, se assustaria, já que nunca ou raramente se depararia com tal cena em seu cotidiano. Em áreas de favelas, a possibilidade de se defrontar com pessoas assassinadas e presenciar conflitos armados e violentos é maior do que em outros espaços territoriais da cidade. Para pessoas de outros segmentos sociais, a ideia da morte violenta decorre do que é apresentado através da mídia.

Como observa Sobchack (2005, p.127), no que se refere ao documentário, “a morte suscita um problema especial na sua representação”, sendo tratada como uma experiência privada e anti-social. Pois os critérios para a visão da morte na ficção não são tão rigorosos como no documentário. Enquanto na ficção é, principalmente, “icônica e simbólica”, sendo algo representável e até corriqueiro, no documentário, a morte é “antes de tudo, indicial”, pois a questão da ética é muito mais rigorosa, neste caso, pelo tabu social que consiste na visualização “real” de eventos de violência e morte.

Em O prisioneiro da grade de ferro, observa-se a figura de um fotógrafo e as fotos feitas por ele, de presos mortos de forma violenta. São imagens chocantes, que só podem ser mostradas sob a forma congelada da fotografia. Segundo Damatta (1991, p.170), os mortos “são entidades tipicamente relacionais e, como tal, comandam atenção e reverência”. Eles são apresentados como uma peça crítica da dinâmica deste universo social.

No texto Os discursos da violência no Brasil, Damatta (1993, p.178) examina como a violência é percebida e discutida no nosso país. São caracterizados dois modelos, denominados, respectivamente, leitura teórica e discurso popular. O primeiro refere-se à violência como consequência da ausência de polícia repressiva. A comunicação deste discurso aconteceria de forma violenta, em tom de denúncia, no qual nada é poupado. Exemplo clássico deste tipo de discurso estaria nos programas de televisão como Brasil urgente, da Rede Bandeirantes e Cidade Alerta, da Rede Record, cujos apresentadores exaltados e aos berros, na maioria das vezes, exigem do Estado mais policiamento nas ruas para prevenir e liquidar a violência. Trata-se de um discurso no qual a compreensão se confunde com o diagnóstico, sendo marcado, frequentemente, por sugestões de como resolver o problema da violência no Brasil, sem espaço para qualquer tipo de dúvida ou contradição. 
O segundo discurso, relativo ao senso comum, é uma narrativa baseada na experiência diária. Neste caso, a violência surge como um mecanismo social indesejável, como uma "ação espontânea, reparadora e direta que rompe os espaços e as barreiras dos costumes, as normas legais, e invade de qualquer maneira o espaço moral do adversário” (DAMATTA, 1993, p.180). A imagem que estaria mais condizente com este tipo de discurso seria a de uma briga ou conflito entre duas ou mais pessoas engajadas num confronto físico.

Os documentários apresentam os dois tipos de discurso. O primeiro, relativo aos disfuncionamentos do Estado, é compartilhado tanto pelas personagens como pelos próprios cineastas. Caracteriza-se pela crítica, mesmo velada, às ausências de autoridade, Estado e Justiça, considerados “o grande algoz” (DAMATTA, 1993, p.179) e responsável pela felicidade ou miséria do povo. No discurso do senso comum, que é pessoal e relacional, a violência aparece como um mecanismo destinado a promover pessoalmente a justiça, quando as corporações legais falham no cumprimento de suas obrigações (DAMATTA, 1993, p.186). Neste nível de percepção, o que conta é o plano pessoal, enquanto o discurso erudito acentua o universal. A coexistência das duas abordagens é condizente com o princípio da lógica contraditorial, que mantêm os paradoxos ao invés de uma síntese perfeita e racionalmente definida, a partir de uma multiplicidade de valores heterogêneos que se combinam, criando certa unicidade.

Os documentários tratam de histórias pessoais, permeadas pela ausência ou impotência do Estado em assumir seu papel de garantia dos direitos e da segurança da população. Os instrumentos legais não se configuram como legítimos e eficientes, considerando que polícia aparece como um sujeito que também aterroriza. A disfunção do Estado na gestão pública pode ser observada nas cenas finais do filme $O$ prisioneiro da grade de ferro, com a inauguração de um presídio, numa clara alusão à continuidade da situação limite representada pela precariedade vista na Casa de Detenção do Carandiru ou nos comentários, em voz over, feitos no desfecho do caso do Ônibus 174, nos quais há uma compilação de depoimentos de vítimas e de especialistas que criticam a ação policial e a ineficiência do Estado no trato com os meninos de rua e crianças carentes, o que facilitaria o surgimento de pessoas como Sandro.

A partir da percepção dos perigos e riscos a que estão sujeitas, as pessoas atuam e fazem o que podem para controlá-los e evitá-los (ZALUAR, 2002, p.24). No exemplo, ocorre a convergência dos discursos descritos. O do senso comum, que consiste em uma ação na qual a força corporal surge como instrumento básico de violação da integridade do outro e no qual 
o ato de violência se configura como físico. Este discurso não se caracteriza por explicitar uma visão econômica e política, mas por exprimir uma posição na qual a violência se relaciona à "maldade humana" ou ao uso da força contra o fraco, pobre ou destituído (DAMATTA, 1993, p.181). As pessoas são apresentadas como vítimas em potencial, a partir da constatação da violência policial sofrida por elas e das experiências dolorosas, violentas ou injustas que tiveram com as instituições encarregadas de representar a lei (ZALUAR, 2004, p.201). As personagens são negras e pobres, com pouca escolaridade, que sofrem discriminação pela sua etnia e situação econômica e social, além da presença dos presos e dos réus e do preconceito que envolve pessoas nesta condição.

Isto ocorre em $O$ prisioneiro da grade de ferro, no qual os presos asseguram a sua defesa, aparelhando-se com armas produzidas por eles mesmos, além da participação em grupos para aumentar o seu domínio na cadeia. Em O cárcere e a rua, há a presa, que acusada de matar o filho, permanece isolada, para não ser morta pelas outras detentas. Em Justiça, há a queixa dos réus, que reclamam da propina exigida pelos policiais, para obterem a liberdade. Nos três casos, se tratam de pessoas que se encontram sob a proteção do Estado, estando aí implicado, mesmo que subjacente, o discurso erudito, que se refere à estrutura do sistema. Em Ônibus 174, Sandro, que também esteve, em várias ocasiões, sob esta mesma proteção, é morto por policiais, no interior de uma viatura da polícia. As pessoas que orbitam ao redor das personagens principais, também estão desprotegidas, sob risco permanente e à mercê da violência, como ocorre em Fala Tu, no qual valem-se do rap, para expressar o seu descontentamento com a própria situação social.

A violência, neste caso, seria uma resposta funcional da sociedade a alguma coisa considerada uma anomalia provocada por um determinado tipo de sistema (DAMATTA, 1993, p.178). Caberia à polícia, em última instância, garantir a segurança dos cidadãos, pois tem ela o dever de prevenir, coibir e conter as diferentes formas de violência e criminalidade. Mas, segundo Baierl (2004, p.155), na história brasileira e na prática concreta das organizações policiais, o seu papel e a sua representação social têm sido profundamente contraditórios. A população, que deveria olhar a polícia como alguém em quem confiar, ao contrário, identifica-a com sujeitos que desrespeitam a lei e agridem as pessoas indistintamente, em vez de transmitir segurança, além de promoverem subornos, ampliando as ações ilegais dos bandidos (BAIERL, 2004, p.156). A violência desenvolve novas formas de socialidade, que desafiam os poderes legalmente instituídos, enfrentando o Estado no controle das favelas, bairros de periferia e presídios. 
No filme Justiça, se observa uma sequência que mostra a defensora pública e o juiz com suas respectivas famílias, em suas casas, assistindo ao noticiário televisivo. Em ambas as televisões passam cenas de ônibus sendo incinerados e a informação de que se trata de incêndios criminosos. Esta imagem funciona como símbolo de uma situação, esboçando-se a relação com a lógica social de ganhar rosto e voz. Esta destruição equivaleria a um "você sabe com quem está falando?” Com a violência surgindo “como um modo drástico de separar e individualizar” (DAMATTA, 1993, p.191).

Esta prática corresponderia a uma das faces da violência no Brasil condizente com as noções relativas à vingança, ao quebra-quebra e ao “sabe com quem está falando?”, conformando-se, respectivamente, às modalidades de reparo, protesto e reconhecimento social. Segundo Damatta (1993, p.186), são tentativas de juntar pela intervenção direta, o plano das leis universais e igualitárias do mundo da rua e a moralidade particularista e hierarquizada do universo da casa, tratando-se de formas institucionalizadas de violência, através das quais se busca transcender essa divisão.

As três modalidades constituiriam maneiras de lidar com as injustiças, fazendo com que os que controlam o sistema legal e a burocracia jurídica e policial sofram de uma ideia de justiça moral. Como ocorre com a organização criminosa Comando Vermelho, originada no interior de prisões brasileiras. Com seu lema Paz, justiça e liberdade, surgiu, inicialmente, com o objetivo de lutar por melhores condições de vida para os presos nas cadeias. Mais tarde, o propósito sofreu um desvio, sendo estendido para o domínio do tráfico de drogas, em várias regiões do país e dentro dos próprios presídios. A lealdade dos criminosos com esta organização é evocada pelos seus líderes e participantes, sob pena de uma infidelidade ao grupo ser paga com a própria vida. Com isso, sincroniza-se a ideia de "justiça” com a de moralidade pessoal (DAMATTA, 1993, p.188).

No texto Três teses sobre a violência (2001), Ricardo Timm de Souza aborda as relações entre as noções de alteridade e violência. São apresentadas três considerações que colaboram para o entendimento da questão, no contexto proposto, referente ao conjunto de filmes estudados.

A primeira tese se refere à violência como negação de uma alteridade. Considerada a partir de “atos que negam a condição de 'outro' do outro, ou seja, daquele que não pertence ao polo de decisão”, numa tentativa de neutralizá-la enquanto tal (TIMM DE SOUZA, 2001, p.9). Sob este domínio, a violência pode se expressar no uso indiscriminado da força física ou psicológica, representada pela dominação do outro, como instrumento para potencializar o 
medo. Neste caso, a violência é associada à desordem, à insegurança e ao confronto direto entre as pessoas, tendo relação com a ausência de mediação, conduzindo à invasão dos espaços e ao encontro cara a cara, no qual a força substitui outros eixos organizatórios, como por exemplo, as mediações da lei (DAMATTA, 1993, p.183).

A segunda tese afirma que "a maior das violências consiste em velar os vínculos profundos que qualquer ato violento tem com qualquer outro ato violento” (TIMM DE SOUZA, 2001, p.9). As infinitas maneiras de manifestação da violência, no mundo contemporâneo, não se dariam com a mesma transparência à visibilidade. Existem formas múltiplas de negação da alteridade, em todos os níveis da vida. A compreensão do sentido que a violência assume no mundo atual passa pela compreensão da desconexão entre a infinita cadeia de fatos que são expressões e traduções da mesma estrutura de negação da alteridade.

Damatta (1993, p.190) observa que "se perante a legislação todos são sujeitos integrais e indivisos, as normas não escritas da moralidade pessoal nos leem como singularidades que ocupam somente uma posição numa teia de relações”. Isto obrigaria a uma leitura dos atos de modo relacional ou relativo aos motivos impostos por outra pessoa. Esta questão também se refere ao envolvimento em determinada estrutura que propicia um estado de violência. Sob este aspecto, os indivíduos devem ser julgados com o pressuposto de que são responsáveis exclusivos pelo que fazem, mas deve-se levar em conta que as pessoas fazem coisas não apenas porque querem, mas, sobretudo, porque uma dada relação assim comanda. Exemplo desta perspectiva está na argumentação de que "Y roubou 'pensando na sua família’” (DAMATTA, 1993, p.190). Neste caso, a ideia de responsabilidade individual e indivisível está em competição com noções antiindividualistas que dizem que este tipo de atribuição de comprometimento seria impossível porque as pessoas têm obrigações para com suas relações.

Na terceira tese, Timm (2001, p.9) questiona uma possível desarticulação da racionalidade violenta, que passe pelo questionamento radical de certos postulados da razão tidos como intocáveis pelo esclarecimento moderno e que, na verdade, acobertam a violência exercida contra outras racionalidades possíveis e reais.

A economia das ilegalidades se reestruturou com o desenvolvimento da sociedade capitalista. Segundo Foucault (2002, p.74), a ilegalidade dos bens foi separada da ilegalidade dos direitos. Esta divisão corresponde a uma oposição de classes, pois, de um lado, a ilegalidade mais acessível às classes populares seria a dos bens, relativa à apropriação violenta de propriedades; de outro, a burguesia, que reservaria para si, a ilegalidade dos 
direitos, a partir da possibilidade de desviar seus próprios regulamentos e leis e de fazer funcionar um imenso setor da circulação econômica por um jogo que se desenrola nas margens da legislação, através de fraudes, evasões fiscais, operações comerciais irregulares, etc.. Trata-se de transgressões, frequentemente impunes no Brasil, graças à burocracia e à ineficiência e lentidão da justiça. Normalmente, o crime é identificado com o castigo recebido. Se os infratores não são julgados e condenados, logo não são identificados com o delito cometido.

\section{CONSIDERAÇÕES FINAIS}

É a sociedade que define, em função de seus interesses próprios, o que deve ser considerado como crime. Portanto, além da complexidade do fenômeno, revela-se a presença de dois códigos em nossa sociedade, complementares e até simétricos. As teorias eruditas que indicam mecanismos políticos abstratos como causa da violência e o discurso pessoal, no qual há a atribuição da violência a uma causa concreta, que dá aos eventos um valor moral (DAMATTA, 1993, p.184).

É no espaço do cotidiano observado nos documentários, que a vida se revela, se faz e se constrói. Os fatos e acontecimentos ganham vida, sentidos e significados e vão construindo trajetórias e caminhos. E neste domínio, a violência e o medo adquirem sentidos. Na apresentação do drama vivido é difícil a identificação de quem são os mocinhos ou os bandidos. Ambos se confundem na tela do cinema. Pois o imaginário conduz à multiplicidade de sentidos que cada pessoa confere à sua existência. Assim, a conexão entre o objetivo e o subjetivo relaciona-se à lógica contraditorial, que leva em consideração o heterogêneo, com a atuação das pessoas retratadas sendo marcada por uma "sequência de instantaneidades, pequenas porções do real, feito de sinceridades sucessivas”, permitindo o seu reconhecimento no conjunto social, a partir da afirmação de sua alteridade (MAFFESOLI, 1999, p.94).

O que tem interesse é o momento, o acontecimento que vale por si mesmo, que está no banal, no cotidiano e não numa situação considerada excepcional. "Cada objeto, através de sua própria banalidade, está cercado de uma aura que faz acontecimento” (MAFFESOLI, 1999, p.194). Cada filme se apresenta como uma duração a ser experimentada, sendo encarado como um conjunto de acontecimentos, que nem sempre terão um desfecho. São resultado das relações humanas e produtores de relações, pois organizam modos de socialidade. Apontam para a falta de saída ou solução imediata dos problemas e das situações que afetam as pessoas. Não há luz no fim do túnel. Em O prisioneiro da grade de ferro, há a 
inauguração de uma nova penitenciária pelo governador de São Paulo, na época, Geraldo Alckmin. Logo a seguir, se observa um homem, no pátio do presídio, declamando uma poesia, que termina com o lema do Comando Vermelho: “paz, justiça e liberdade”. Também são apresentados depoimentos de ex-diretores do Complexo Penitenciário do Carandiru que criticam o sistema carcerário. Em Ônibus 174, se apresenta uma situação dicotômica. O enterro de Geisa, morta durante a ação policial, lotado de pessoas que lá estão para prestar a última homenagem e o enterro de Sandro, o sequestrador, que é acompanhado apenas por sua mãe adotiva. Evidência de um sistema de contrastes que indica a continuidade das circunstâncias anteriormente apresentadas. Em Justiça, Fala Tu e O cárcere e a rua, não há desfechos para as pessoas que são mostradas. Elas continuam a seguir suas vidas, com os mesmos problemas que se tornaram conhecidos do espectador, no decurso do filme, como o desemprego, as dificuldades financeiras e um permanente estado de precariedade que marca o cotidiano.

Desta perspectiva, a sociedade se reflete e se concretiza em todas as suas manifestações, encarnando-se tanto na polícia quanto no criminoso. Violência e concórdia seriam modos pelos quais um sistema de valores se revela, em uma sociedade que se mostra tanto pelo que preza como sagrado quanto pelo que teme e despreza como o crime e a violência.

\section{REFERÊNCIAS}

AUMONT, Jacques. et. al. A estética do filme. 2.ed. Campinas: Papirus, 2002.

BAIERL, Luzia Fátima. Da violência visível ao invisível da violência. São Paulo: Cortez Editora, 2004.

BOURRIAUD, Nicolas. Estética relacional. São Paulo: Martins Fontes, 2009.

CALDEIRA, Teresa Pires do Rio. A política dos outros: o cotidiano dos moradores da periferia e o que pensam do poder e dos poderosos. São Paulo: Editora Brasiliense, 1984.

DADOUN, Roger. A violência: ensaio acerca do “homo violens”. Rio de Janeiro: Difel, 1998.

DAMATTA, Roberto. Carnavais, malandros e heróis. Rio De Janeiro: Zahar Editores, 1981.

Conta de mentiroso: sete ensaios de antropologia brasileira. Rio de Janeiro: Rocco, 1993. 
FOUCAULT, Michel. Vigiar e punir: nascimento da prisão. Petrópolis: Vozes, 2002.

HAMBURGER, Esther. Violência e pobreza no cinema brasileiro recente. Novos estudos, n. 78, p.113-128, 2007.

JORON, Philipe. A parte maldita e o lado escuro da TV brasileira. Revista Famecos. Porto Alegre: Edipucrs, n. 26, abril 2005.

LABAKI, Amir. É tudo verdade. São Paulo: Francis, 2005.

MAFFESOLI, Michel. Mediações simbólicas: a imagem como vínculo social. In: MARTINS, Francisco Menezes; SILVA, Juremir Machado da (org.). Para navegar no século XXI. Porto Alegre: Sulina/Edipucrs, 2003.

No fundo das aparências. Petrópolis: Vozes, 1999.

MICHAUD, Yves. A Violência. São Paulo: Editora Ática, 2001.

RAMOS, Fernão Pessoa. Narcisismo às avessas. Folha de São Paulo. São Paulo, 03 ago. 2003. Caderno Mais!

ROSSINI, Miriam de Souza. Favelas e favelados: a representação da marginalidade urbana no cinema brasileiro. Sessões do Imaginário. Porto Alegre: Edipucrs. n. 10, nov. 2003.

SILVA, Juremir Machado da. As tecnologias do imaginário. Porto Alegre: Sulina, 2003.

SOBCHACK, Vivian. Inscrevendo o espaço ético: dez proposições sobre morte, representação e documentário. In: RAMOS, Fernão Pessoa. et. al. Teoria contemporânea do cinema. São Paulo: Editora Senac, 2005.

SODRÉ, Muniz. Sociedade, mídia e violência. Porto Alegre/Sulina: Edipucrs, 2006.

SOUZA, Ricardo Timm de. Três teses sobre violência: Violência e Alteridade no contexto contemporâneo. Civitas - Revista de Ciências Sociais, Ano 1, n. 2, dez. 2001. Disponível em: <http://revistaseletronicas.pucrs.br>

ZALUAR, Alba. Dilemas da segurança pública no Brasil. Desarmamento, segurança pública e cultura de paz. Rio de Janeiro: Fundação Konrad Adenauer, 2005. v.3. Disponível em: <http://www.ims.uerj.br/nupevi/desarmamento.pdf>

FGV, 2004. Integração perversa: pobreza e tráfico de drogas. Rio de Janeiro: Editora

Oito temas para debate: violência e segurança pública. Revista Sociologia, problemas e práticas, n. 38, p.19-24, 2002.

Disponível em: http://www.scielo.oces.mctes.pt/pdf/spp/n38/n38a02.pdf 
Original recebido em: 07/01/2013

Aceito para a publicação em: 20/07/2013

Resumo do autor:

Isabel é Bolsista de Estágio Pós-doutoral DOCFIX Capes/Fapergs, junto ao Programa de Pósgraduação em Comunicação da Universidade Federal de Santa Maria (UFSM). Doutora em Comunicação Social pela Pontifícia Universidade Católica Do Rio Grande do Sul (Pucrs). 